\title{
International Relations and Cooperation Between Poland and China within the Context of the New Silk Road and Central and Eastern Europe
}

\begin{abstract}
Summary
The paper deals with the analysis of the bilateral relations of the People's Republic of China and the Republic of Poland, in the context of the multilateral initiative "16 +1 ". After a brief review of the history of their relations, the author focuses on the current cooperation between China and Poland, paying special attention to its regional dimension. The paper emphasizes the importance of bilateral and multilateral cooperation between China and the countries of Central and Eastern Europe. The central part of the paper is dedicated to analysis of the institutional mechanisms of cooperation, with a special emphasis on trade and investment, as well on the challenges facing the China-Poland cooperation. In the final part of the paper, the author gives his recommendations for further development of bilateral cooperation and its elevation to a higher level.
\end{abstract}

Key words:

Initiative $16+1$, People's Republic of China, Republic of Poland, Central Europe, Eastern Europe, bilateral cooperation, multilateral cooperation, trade, investment, institutional mechanisms 


\section{INTRODUCTION}

The chapter examines international relations and cooperation between Poland and China in the context of the New Silk Road (NSR) ${ }^{1}$ while taking a broader perspective of Central and Eastern Europe (CEE) and a dialogue of the countries from the region with China within 16+1 framework. It starts with historical background and followed by current directions of the relations between Poland and China. Next, it discusses the role of Central and Eastern Europe in collaboration with China. It further elaborates on the institutional mechanism of the bilateral and multilateral relations as a crucial setting on which the cooperation is evolving, focusing primarily on trade, investment flows and other forms of institutional dialogue and cooperation. Furthermore, the challenges for further cooperation between Poland and China will be addressed in a broader perspective of CEE. The chapter concludes with recommendation for enhancing relations and cooperation with China and bringing it to a higher level.

In the following chapter the qualitative methods and descriptive statistics were used. The scope of the research covers the flows of trade and capital, in particular in form of a foreign direct investment (FDI) and refers to bilateral relations between Poland and China. In numerous aspects, the analysis was enlarged to Central and Eastern European countries (CEEC) or even more broadly to the European Union (EU). The time series range from 1995 till 2017 when possible and the predictions are made till 2030.

\section{HISTORICAL BACKGROUND AND CURRENT DIRECTIONS OF THE RELATIONS BETWEEN POLAND AND CHINA}

Poland and China have a long history of a relationship. China recognized Poland as an independent country in 1920 after the World War One. At that time however, it wasn't in the priorities neither of Poland nor of China to build up the bilateral relations due to the need to rebuild the country in case of Poland and internal issues in circumstance of China. On the other hand,

The rejuvenation of the New Silk Road first announced by the Chinese President Xi Jinping in Astana, Kazakhstan (2013) evolved into 'One Belt, One Road' (OBOR) concept, as applied by the Chinese government in 2014, and later into 'Belt and Road Initiative' (BRI), as currently term. The author of the chapter consistently uses the term 'New Silk Road' (NSR) to avoid misunderstandings, while capturing all the elements of the concept. 
Poland was one of the very first countries to recognize People's Republic of China (PRC) what followed with official establishment of diplomatic relations between the two countries on $7^{\text {th }}$ of October 1949, only 6 days after Mao Zedong proclaimed the PRC on $1^{\text {st }}$ of October. The relationship since that time was going through highs and laws mainly as a consequence of political climate on both ends. The bilateral relations of modern time are based on and regulated by numerous intergovernmental statements and agreements including:

- Agreement on avoiding double taxation (1988),

- Agreement on support and protection on mutual investment (1988),

- Agreement on economic cooperation (2004),

- Join Statement on Strategic Partnership (2011),

- Join Statement on Comprehensive Strategic Partnership (2016).

The relations between Poland and China entered another level after establishment of the dialogue between China and Central and Eastern European countries. It was initiated during the China-Central Europe-Poland Economic Forum held in Warsaw on $26^{\text {th }}$ of April 2012 with the presence of the Chinese Prime Minister Wen Jiabao and the heads of states from the region, what will be further discussed in the next section.

\section{CENTRAL AND EASTERN EUROPE IN COOPERATION WITH CHINA}

The relations between Europe at large and China didn't remain without the influence after the breakdown of the communism, landmarked by the fall of the Berlin Wall in 1989, followed by the unification of the East and West Germany, economic transformation of Central and Eastern European countries into market economies and last but not least the enlargements of the EU. Political and economic relations of CEEC with China, as well as with other East Asian markets were rather limited during the first decade of transformation compared to those with Western Europe and didn't attend the highest priority in foreign policies. The countries were mostly concentrated on restructuring their economies, adjusting to the new political system while resetting their position in transforming Europe. Therefore, current economic relations still don't reflect the potential of Chinese markets and don't make the most of the possibilities offered by Central and Eastern European economies (Nawrot 2013). 
The breakthrough in mutual relations between China and Central and Eastern European countries were marked during the China-Central Europe-Poland Economic Forum held in Warsaw on $26^{\text {th }}$ of April 2012. During the Forum twelve proposals were put forward by Chinese Prime Minister Wen Jiabao to promote cooperation with 16 countries from the region, namely Albania, Bosnia and Herzegovina, Bulgaria, Croatia, Czech Republic, Estonia, Hungary, Latvia, Lithuania, Macedonia, Montenegro, Poland, Romania, Serbia, Slovakia and Slovenia. The establishment of the common Secretariat was the priority as a platform served to facilitate the implementation of the proposals. The official establishment of the Secretariat for Cooperation for Central and Eastern Europe in Beijing followed the same year in September and was set by the Chinese Ministry of Foreign Affairs (Nawrot 2015).

Among the twelve proposals the 10 billion USD credit line for Central and Eastern European states was set by the Chinese government targeted to boost bilateral business and trade by supporting joint projects mainly in infrastructure, new technologies and green energy. An increase in trade to $\$ 100$ billion with countries from the region was expected by 2015. The cooperation was further promoted in science, education, culture and tourism.

The undertaken initiatives were perceived as a good sign of strengthening the cooperation between China and Central and Eastern European countries, with Poland as a biggest market in the region. The Chinese leaders stressed by several occasions that consolidating cooperation between China and Central and Eastern European countries was an important component in enhancing China-Europe cooperation which should help China and Europe make joint efforts to tackle challenges and promote their comprehensive and strategic partnership to a higher level.

Besides, closer cooperation between China and Central and Eastern European countries was believed to serve as a chance to balance the trade exchange with China, as Chinese export has been dominant in all the countries of the region. It means, that in all cases the asymmetry in bilateral trade has been significant.

The necessity to strengthen common trust and understanding between Europe and China was particularly important and apparent in Central and Eastern European countries. The communication between China and Europe has increased significantly over the last decade, through people-topeople contact, flow of tourists and mostly trade and cross border investments thus contributing to better understanding between Europe and China. This is an achievement of great importance for China and European countries. However, the still existing asymmetry of information flow and knowledge between Europe and China must be mentioned. Therefore, the 
need arises to decrease the existing gap on many levels starting with the bottom-up level till the governmental one.

Furthermore, certain Central and Eastern European countries are part of the European Union market. As such the policy towards China should not be inconsistent with European Union's policy. The hopes and expectations from strengthening ties with China were prevalence among the countries from Central and Eastern Europe strongly from the beginning of the New Silk Road initiative and it seems that they have emerged significantly over the very last years. It must be however emphasized that the initial optimism among CEEC significantly decreased and has been replaced with rather sceptical and caution stance, as result of not necessarily economically effective outcomes - as excepted - over the last five years of cooperation. It is in the interest and free will of all sides that political declarations initiated by the Chinese leaders and the leaders from CEEC will be transformed into the real economy.

\section{INSTITUTIONAL MECHANISMS OF A RELATIONS WITH CHINA}

Institutional framework of relations with China consists of numerous mechanisms of bilateral and multilateral character including trade, capital flows, summits, other economic cooperation and consultations mechanisms, Asian Infrastructure and Investment Bank (AIIB), Information and Foreign Investment Agencies, industry meetings and conferences, fairs, local government partnerships, special economic zones, among others. The following session will explore primarily trade and investment patterns, followed by the discussion of other possible new directions, dimensions and fields of cooperation with China. 


\subsection{Pattern of trade between Poland and China}

from the European perspective

Trade is the most important form of cooperation between China and Poland. As for Poland, in 2014 the trade exchange with China - according to Polish Central Statistical Office - was exceeding 80.5 billion PLN, compared to only 1.2 billion USD in mid-nineties (GUS 2016). Both exports and imports were gradually growing over the last two decades. Between 2004 and 2014 exports from Poland to China more than tripled and imports from China has nearly increased fivefold (Fig. 1). However, the substantial asymmetry in trade cannot be overlooked as Polish export to China constitutes only around $10 \%$ of its import from China and this asymmetry has been observed for years now with even growing tendency. As for 2015 the share of Chinese imports in total imports of Poland exceeded $11 \%$ and the share of exports to China in total exports of Poland remain at 1\% (ibidem). Consequently, Chinese role among Polish trade partners has been gaining the importance. China is now the most important trade partner of Poland in East Asia - estimated by the value of the bilateral trade and the value of Polish import. China also took the second position among import partners - after Germany. It clearly means that China is a partner of strategic importance in imports. Based on predictions of foreign trade between Poland and China in years 2016-2030, both exports and imports are expected to grow and the asymmetry in trade to deepen - Fig. 2.

Fig. 1. Foreign trade between Poland and China in 1995-2015 (in PLN million)

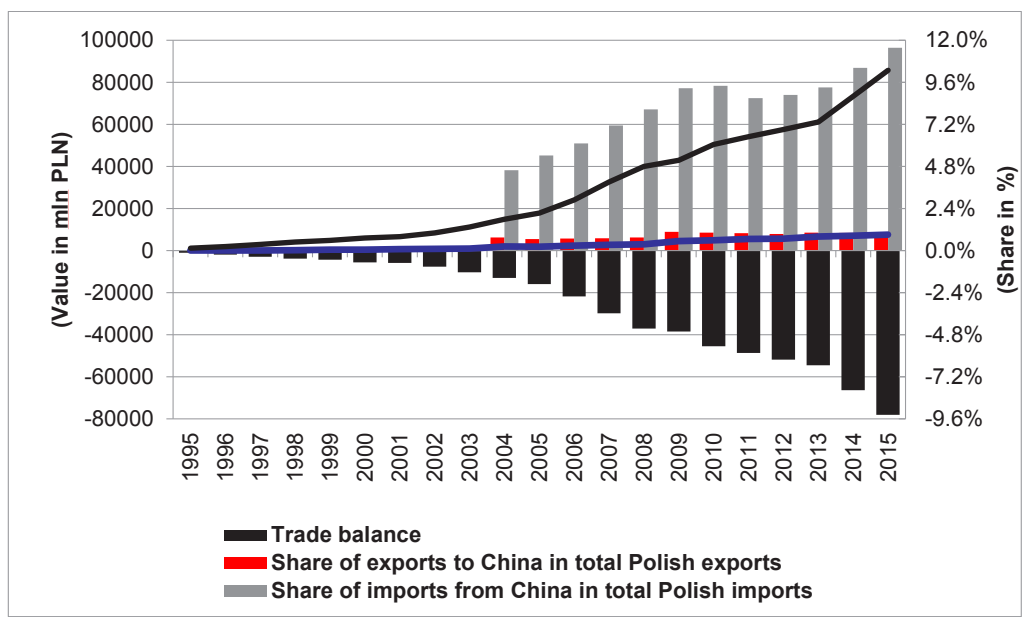

Source: author's own elaboration based on Polish Statistical Office data. 
Fig. 2. Predictions of foreign trade between Poland and China in 2016-2030 (in PLN million)

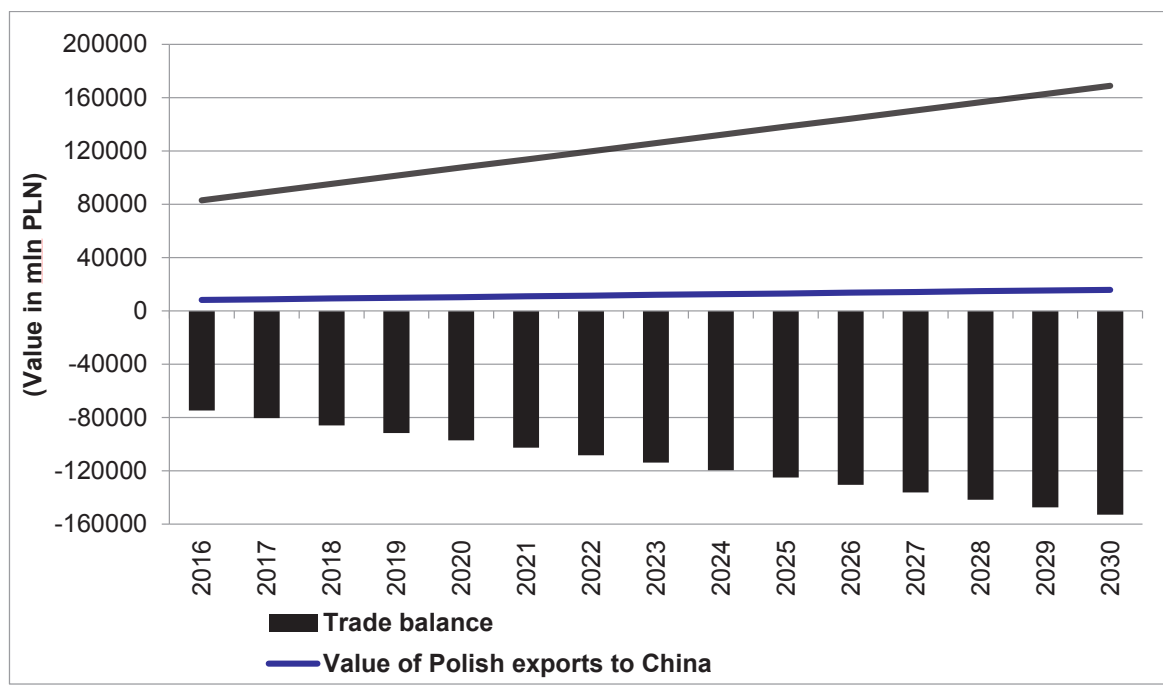

Source: author's analysis based on Polish Statistical Office data.

According to the European Union statistics, the foreign trade of Poland and China exceeded EUR 14.9 billion in 2015, what was slightly less comparing to the Polish data source. Exports was estimated around EUR 1.82 billion and imports cca. EUR 13.1 billion. The trade dynamics was particularly high after 2004, and in 2007 accounted for cca. 40\% comparing to the previous year. The rise and decrease in trade resulted - among other factors - from ban on import of pork from Poland, imposed by China in 2014 (Eurostat 2016).

For comparison, bilateral trade of European Union and China rose from EUR 15.9 billion in 1990 to EUR 72.2 billion in 1999, reaching EUR 520.8 billion in 2015 (Eurostat 2016). In 1979, just after reforms introduced by China in 1978, the total trade volume was estimated at modest EUR 3.4 billion (Eurostat 2016). The impressive grow of trade in the following years positioned the EU as China's most important trading partner and China as the EU's biggest importing market and second largest trading partner after United States. EU exports to China in 2011 increased by $20.3 \%$ to EUR 136.2 billion and Chinese exports to the EU reached EUR 292.1 billion, constituting an $8.9 \%$ share of total EU exports and a $17.3 \%$ share of total EU imports - see Fig. 3. 
Fig. 3. EU external trade trends with China in 1980-2015 (EUR billion)

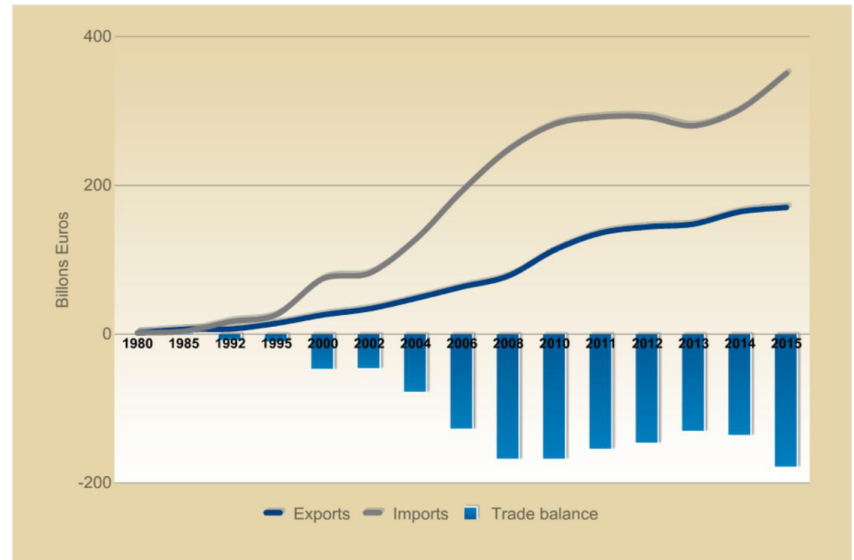

Explanations: 1980 includes trade for EU-9; 1985 for EU-10; 1992 for EU-12; 1995-2002 for EU15; 2004-2006 for EU-25; from 2008 for EU-27.

Source: based on data from Eurostat 2016; Eurostat 2012; Eurostat, 2011.

The value of both export and import was further growing in the following years, reaching subsequently in 2015 EUR 170.4 and EUR 350.4. The existing trade asymmetry - as clearly seen on figure 3 - further increased by almost 31\% compared to 2014 and the EU trade deficit with China was estimated at EUR 179.9 billion in 2015 (Eurostat 2016). Detailed data on the EU external trade trends with China over the last three decades are presented at Fig. 3, showing the dramatic increase in both exports and imports while revealing the substantial and growing trade deficit especially in last ten years. Consequently, in 2015 Polish exports to China accounted for $1.06 \%$ of the total EU exports to China and Polish imports from China accounted for $3.7 \%$ of total EU imports from China.

Among the countries from Central and Eastern Europe, Poland remains the most important trade partner of China, followed by the Czech Republic and Hungary - see Table 1. 
Table 1. Foreign trade between China and selected CEEs, 2015 (in EUR million)

\begin{tabular}{l|c|c|c|c}
\hline \multicolumn{1}{c|}{ Country } & Exports & Imports & $\begin{array}{c}\text { Total trade } \\
\text { turnover }\end{array}$ & Trade balance \\
\hline 1. Poland & 1819,3 & 13083,4 & 14902,7 & $-11264,1$ \\
\hline 2. Czech Republic & 1671,5 & 10528,3 & 12199,8 & $-88568,8$ \\
\hline 3. Hungary & 1262,4 & 5150,1 & 6412,5 & $-3887,7$ \\
\hline 4. Slovakia & 1019,9 & 2720,2 & 3740,1 & $-1700,3$ \\
\hline 5. Romania & 525,1 & 2887,4 & 3412,5 & $-2362,3$ \\
\hline 6. Slovenia & 294,0 & 1458,8 & 1752,8 & $-1164,8$ \\
\hline 7. Bulgaria & 550,7 & 966,4 & 1517,1 & $-415,7$ \\
\hline 8. Lithuania & 102,4 & 725,3 & 827,7 & $-622,9$ \\
\hline 9. Estonia & 135,7 & 625,2 & 760,9 & $-489,5$ \\
\hline 10. Croatia & 70,1 & 524,7 & 594,8 & $-454,6$ \\
\hline 11. Latvia & 108,4 & 416,5 & 524,9 & $-308,1$ \\
\hline
\end{tabular}

Source: Authors' analysis based on Eurostat data.

Regarding the structure of trade, the main Polish exports to China include base metals and articles thereof (mostly copper and copper products) and machinery and mechanical appliances, electrical and electro technical equipment. In 2015, they constituted respectively $38.5 \%$ and $25.1 \%$ of total Polish exports to China. Other important Polish export to China includes plastics and rubber and articles thereof (7.07\%), miscellaneous manufactured articles (6.64\%) and products of the chemical industry (5.14\%) - compare Table 2. The main products in Polish exports to China includes: copper, furniture, chocolate products, vehicles parts and accessories, telephone apparatuses, electrical switches, synthetic rubber, gas turbines, chemicals and cables (Table 2). 
Table 2. Foreign trade between Poland and China by product groups, 2015 (in EUR million)

\begin{tabular}{|c|c|c|c|c|}
\hline Product group & $\begin{array}{c}\text { Exports } \\
\text { (in EUR mln) }\end{array}$ & $\begin{array}{c}\text { Imports } \\
\text { (in EUR mln) }\end{array}$ & $\begin{array}{c}\text { Exports } \\
\text { (in \%) }\end{array}$ & $\begin{array}{l}\text { Imports } \\
\text { (in \%) }\end{array}$ \\
\hline Total & 1819,7 & 20483,3 & 100 & 100 \\
\hline $\begin{array}{l}\text { I - Live animals; animal } \\
\text { products }\end{array}$ & 68,2 & 152,1 & 3,75 & 0,74 \\
\hline II - Vegetable products & 8,1 & 94,9 & 0,45 & 0,46 \\
\hline III - Fats and oils & 0,03 & 1,9 & 0,00 & 0,01 \\
\hline IV - Prepared foodstuffs & 50,9 & 67,2 & 2,80 & 0,33 \\
\hline V - Mineral products & 22,6 & 57,7 & 1,24 & 0,28 \\
\hline $\begin{array}{l}\text { VI - Products of the chemi- } \\
\text { cal industry }\end{array}$ & 93,6 & 571,1 & 5,14 & 2,79 \\
\hline $\begin{array}{l}\text { VII - Plastics and rubber } \\
\text { and articles thereof }\end{array}$ & 128,6 & 591,8 & 7,07 & 2,89 \\
\hline $\begin{array}{l}\text { VIII - Raw hides and skins, } \\
\text { articles thereof }\end{array}$ & 5,5 & 285,9 & 0,30 & 1,40 \\
\hline $\begin{array}{l}\text { IX - Wood and articles of } \\
\text { wood }\end{array}$ & 9,4 & 78,9 & 0,52 & 0,39 \\
\hline $\begin{array}{l}\mathrm{X} \text { - Pulp of wood, paper, } \\
\text { paperboard and articles } \\
\text { thereof }\end{array}$ & 11,2 & 105,9 & 0,62 & 0,52 \\
\hline $\begin{array}{l}\text { XI - Textiles and textile } \\
\text { articles }\end{array}$ & 11,2 & 2247,8 & 0,62 & 10,97 \\
\hline $\begin{array}{l}\text { XII - Footwear, headgear, } \\
\text { etc. }\end{array}$ & 0,9 & 624,9 & 0,05 & 3,05 \\
\hline $\begin{array}{l}\text { XIII - Articles of stone, ce- } \\
\text { ramic products, glass }\end{array}$ & 25,6 & 267,0 & 1,41 & 1,30 \\
\hline $\begin{array}{l}\text { XIV - Pearls, precious stones } \\
\text { and metals, articles thereof }\end{array}$ & 0,6 & 69,6 & 0,03 & 0,34 \\
\hline $\begin{array}{l}\text { XV - Base metals and artic- } \\
\text { les thereof }\end{array}$ & 699,7 & 1276,6 & 38,45 & 6,23 \\
\hline
\end{tabular}




\begin{tabular}{|c|c|c|c|c|}
\hline $\begin{array}{l}\text { XVI - Machinery and me- } \\
\text { chanical appliances, elec- } \\
\text { trical and electrotechnical } \\
\text { equipment }\end{array}$ & 456,7 & 11251,9 & 25,10 & 54,93 \\
\hline XVII - Transport equipment & 70,3 & 451,8 & 3,86 & 2,21 \\
\hline $\begin{array}{l}\text { XVIII - Optical, photograp- } \\
\text { hic, measuring, checking in- } \\
\text { struments, etc. }\end{array}$ & 35,5 & 578,6 & 1,95 & 2,82 \\
\hline XIX - Arms and ammunition & - & 9,2 & - & 0,04 \\
\hline $\begin{array}{l}\text { XX - Miscellaneous manu- } \\
\text { factured articles }\end{array}$ & 120,8 & 1697,4 & 6,64 & 8,29 \\
\hline $\begin{array}{l}\text { XXI - Works of art, collec- } \\
\text { tors' pieces and antiques }\end{array}$ & 0,5 & 0,8 & 0,03 & 0,00 \\
\hline
\end{tabular}

Source: Authors' calculations based in Polish Central Statistical Office data.

The imports from China is highly dominated by machinery and mechanical appliances, electrical and electro technical equipment, which constituted nearly $55 \%$ of Chinese imports in 2015 . The value of the machinery section reached EUR 11.3 billion. Other imports from China include textiles and textile articles (10.97\%), miscellaneous manufactured articles (8.29\%) and base metals and articles thereof (6.23\%) - Table 2 . The main products imported from China include telephone and television apparatuses, computers and spare parts, toys, transformers, lamps and lamp holders, shoes, printing machinery spare parts, suitcases and bags, vehicles' spare parts. The structure of exports over the years slightly improved as the share of highly processed articles has increased (GUS 2016).

\subsection{Investment flows between Poland and China}

The flow of capital between Poland and China, as well as cooperation in investment, science and technology has been rather limited not reflecting the existing potential on both sides. The flow and the stock of Chinese foreign direct investment in Poland and Polish FDI in China are negligible. The value of Chinese FDI in Poland in 2014 amounted USD 91.6 million, making $0.77 \%$ of total foreign direct investment inflows to Poland. The outflow of Polish FDI to China in the same year was even smaller, reaching $0.04 \%$ of Polish total outflow (NBP 2016). It means that Polish companies invest very little in China. 
It should be however indicated, that in recent years, the influx of capital from China and Hong Kong has been significantly increasing, putting these markets at the forefront of East and South Asian partners. Besides China, cooperation in investment has been established with the countries of ASEAN-5, namely the Philippines, Indonesia, Malaysia, Thailand and Singapore, as well as Japan, South Korea and India. Particularly important place among foreign investors from East Asia has been taken by the South Korea, with major investments of Daewoo, LG Electronics and Samsung Electronics. In addition, at the beginning of the twenty-first century interest of investors from Japan has increased. Thus, Japan occupies a high position in the ranking of the investors in the region (Nawrot 2012a). In the last two years, a decrease in the inflow of investments into Poland has occurred, as well as the withdrawal of capital and divestments. The main investors in Poland remain developed countries - the US, the EU countries, mainly Germany, Luxembourg, Italy and the United Kingdom. The relatively small flow of capital between Poland and China can be associated to the insufficient promotional activities, and, consequently, poor knowledge of Chinese investors on the Polish market, but also Polish in the Chinese market. With respect to Polish traders the lack of sufficient investment capital is another issue to be mentioned.

According to the Polish Central Statistical Office at the end of 2013 there were 826 companies with Chinese capital registered in Poland. Among them, 14 companies had more than USD 1 million registered foreign capital, and most of them - 706 - employed less than 10 people (GUS 2016).

Chinese investors in Poland in 2007-2015 have been mainly located in manufacturing - electronics, machinery, plastics, ICT industry, and distribution of commodities (wholesale and retail trade). In 2012 two Chinese banks opened their branches in Poland - the Bank of China and the Commercial Bank of China. Polish companies which invested in China include Selena, Bioton, Rafako, Kopex, Fasing. Among the industries of most interest are coal mining machinery, medicines, construction chemical materials, textile industry and foodstuffs production and sale.

Among the CEEC the biggest stock of Chinese FDI is recorded in Hungary and in 2014 it exceeded USD 556 million. It was more than double comparing to the Czech Republic, Romania, Bulgaria - main destinations for Chinese FDI, next to Poland. The stock of Chinese FDI in Poland was estimated around USD 329 million (Nawrot 2018). The predictions show maintenance of this tendency in the years to come.

In Central and Eastern Europe, including Poland, Chinese investments are made mainly in the infrastructure, industry and raw materials. Although the industry remains the main sector of foreign investment in Cen- 
tral and Eastern Europe, we should expect increasing interest in the services sector.

As declared by Chinese leaders joint projects not only in infrastructure, but also in new technologies and renewable energy will be supported. This demonstrates the attitude and the possibilities of cooperation in high-technology sectors. We can further expect joint scientific research projects and cultural intensification of tourist traffic and interpersonal dialogue, what should further strengthen cooperation, especially in business and commerce.

\section{THE POSSIBLE NEW DIRECTIONS, DIMENSIONS AND FIELDS OF COOPERATION}

Five years after the rejuvenation of the Silk Road and the announcement of the New Silk Road by the Chinese President Xi Jinping in Astana, Kazakhstan (2013), the world economy looks significantly different and so is China, as well as Central and Eastern European countries. The world is undergoing tremendous changes with accelerated speed. Emerging markets are gaining the importance while integrating within the system of the world economy. Old powers, with a leading role of the USA, are redefining and repositioning their role in the existing world order. New non-state actors have emerged and are gaining the importance, including civil society, cities and megacities. Moreover, the growing interdependence of markets require a common and comprehensive response and the responsibility for the global issues, including environment, climate change, inequality, security, resolving the existing conflicts and preventing the potential ones.

Thus, discussing potential new directions in practical cooperation between China, Poland and Central and Eastern European countries two issues seems crucial to be considered, namely ${ }^{2}$ : (i) cooperation with non-state actors; (ii) cooperation for shared goals, what will be discussed in more detail below. Before the brief elaboration of these two points, it is important to further stress that in parallel to practical cooperation those directions require also deep theoretical discussions and empirical research of both multidisciplinary and interdisciplinary character and across the global society.

Referring first to the issue of non-state actors, cities and in particular megacities $^{3}$ are drawing particular attention. As recognized by i.e. Kleer

This part of the chapter is mainly based on work of Nawrot (2018).

Megacities are defined as urban agglomeration with the excess of 10 million inhabitants. 
and Nawrot (2018) the rise of megacities represents a new phenomenon of the $21^{\text {st }}$ century, which is occurring on a rapidly growing scale and with growing importance. From the global outlook, as well as standpoint of China, and perspective of China-CEEC cooperation it is significant for at least four interconnected reasons, namely:

- the growth of the world population,

- growth of urbanization with the rise of agglomeration of megacities worldwide,

- growth of power of megacities,

- lessons and implications from China's urbanization and China's megacities for the world community.

The rise of megacities has been particularly visible in Asia, which is currently home to eight out of the world's 10 largest urban agglomerations, according to Demographia (2016). Majority of existing and projected megacities are currently situated in China - see Figure 4, ranging in terms of the population number to the rate of their growth. Nevertheless, it would be incorrect to lump all the Asian megacities together (or, a fortiori, to assume that the Asian's megacities are largely alike) (Nawrot 2015). This is particularly due to China's megacities with some distinct Chinese characteristics, what will be discussed briefly in next part of this section.

Fig. 4. Chinese megacities in 2015

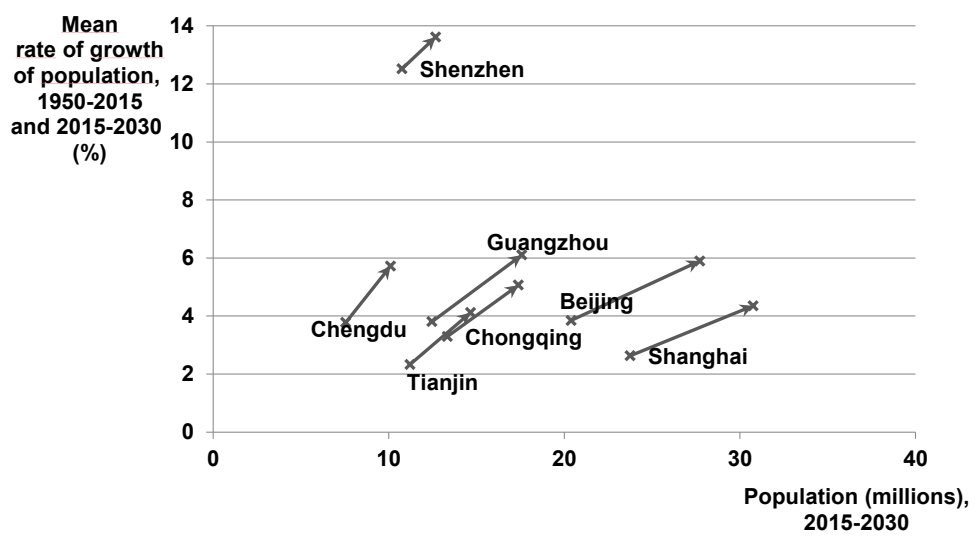

Explanations: the starting point of each vector represents the population in 2015 and mean rate of growth of population in 1950-2015 whereas the end marks the population in 2030; the slope of the vector depicts the mean rate of growth of population in 2015-2030.

Source: authors' analysis and calculations on data from UNDESA (2014). 
The distinctiveness of the Chinese megacities is characterized by two unique features. First of all, their emergence was a top-down process, because the introduction of the market economy in China, which started in the late 1980s, has taken place under the strict control of the state leadership and the power wielded by the Communist Party. Secondly, the influx of people to major agglomerations, such as Shanghai and Beijing, has been a controlled process and all new arrivals are required to obtain residence permits - under the hukou system. Despite that there still are, of course, underprivileged inhabitants who are not official residents and, by the same token, cannot avail themselves of certain state-provided benefits (Kleer and Nawrot 2018). The authorities are trying to resolve problems related to the consequences of the hukou system, as discussed i.e. by Wenmeng (2018). There are, however, plans to still relocate millions of people from rural areas to cities in the coming years, as the largest potential in expanding internal demand in China is considered through urbanization, identified by the state as main contributors to economic growth in the coming decade (Keqiang 2012; Nawrot 2012b: 18; Changsheng and Jianwu 2014: 38; World Bank and DRC 2014). Thus, it can be concluded that there are numerous lessons from China's experiences in urbanization and governance of megacities, especially for fast growing megacities in developing countries. This very much refers to the fact, that China managed to govern fast or even very fast growth of cities with planning and interactions between central and municipal authorities. And in all this - what might be the most important - with a decreasing poverty and the absence of slums in cities.

Finally the observed rise of megacities, leave us without the doubt about their growing potential and power as in some cases they contribute more than one-third of the domestic product of the countries where they are situated and are becoming unique entities in their own right, challenging the developmental policies, governance and cohesion of states. This requires in depth studies and theoretical consideration in the future.

Another important aspect and perhaps the most significant and datum to everything around us is that we live in civilizational turning points - from industrial civilisation to knowledge based civilisation. Being at the turning points adds to the complexity of challenges the human civilization is facing no matter of the geographical location of the country or even context of its economic development. Thus, in all that changes, and to some extend because of it, we can expect a reshape of the world order and redefinition of existing economic systems. And no matter what shape it ends up being, we need to be aware about the future of humanity. And as such we need to find ways and fields of cooperation for global issues and problems our civilization faces. 
New Silk Road as transcontinental phenomenon of cooperation seems to be suitable platform for collaboration for shared goals. "16+1" mechanism being a part of that framework should thus extend a focus from own interest of individual sites and two-sided economic benefits of stakeholders involved to broader and more useful collaboration (Nawrot 2017).

Possible fields might include international security, environmental issues, urbanisation challenges including energy and transportation, communication, sanitation and water supply. Growing urban inequality, poverty and exclusion in fast growing agglomeration needs to be addressed. Better understanding of different cultures, cultures systems and multiculturalism seems further crucial. The future of work and AI are another areas for deep discussion and solutions - just to point a few.

Worth mentioned initiatives of transcontinental and transcultural character between China and Central and Eastern European countries are already existing research and academic network. One to mention is " $16+1$ High level Academic Platform" - a first research network of scientific institutions from Central and Eastern Europe and China established in Warsaw in 2016 and designed to foster cooperation between academic institutions in the framework of a regional cooperation in the formula "16 + 1" (PAP 2016; UEP 2016; Polish Science 2016).

The established research network of scientific institutions from Central and Eastern Europe and from China being a result of long-term efforts and the work of researchers from the partner institutions provides opportunities for scientific and research cooperation, interdisciplinary projects, exchange of scientists and students. In addition, and perhaps more importantly, it is a platform for dialogue and collaboration on global issues and joint research projects in various fields such as economics, management, medicine, commodity science, construction, geology, electro mechanics, telecommunication, biology, chemistry, meteorology and many others. This is a first step to establish broader cooperation among universities and academic institutions from China and Central and Eastern European countries.

Another cooperation between China and CEEC in academia to be mentioned are The China-CEE Think Tanks Network and The China-CEE Institute, as discussed by Oehler-Sincai (2017).

Academic cooperation is a crucial pillar of the relations between China and Central and Eastern European countries in the context of the New Silk Road. There is no better way to build trust and understanding than people-to-people contact. Closer cooperation at the academic level should enable flow of ideas, values, innovations and innovative thoughts to benefit from synergies, build mutual understanding between nations and to bring regions closer together, concentrating on similarities rather than ob- 
stacles and impediments, contributing to the wealth of nations, civilization progress and harmonious global community.

\section{ACTUAL CHALLENGES AND RECOMMENDATION FOR ENHANCING COOPERATION WITH CHINA}

The potential of Chinese economy and perspectives for further growth and development, as well as the growing interdependence between European countries and China underpins the importance of strengthening mutual ties, building comprehensive and strategic partnership in bilateral and multilateral terms. There are however several challenges ${ }^{4}$, which will be briefly discussed below.

A characteristic feature of the relations with China is its asymmetric nature. For years, a negative trade balance has been recorded, and what is often emphasized, Polish exports to China is only one-tenth of imports from China. This is one of the most crucial challenges to deal with in modern relations with China. Consequently, Polish trade policy main goal is to balance the trade flows between the two countries, and thus enhance the Polish exports to China. Changing the existing asymmetries will require concrete projects and effective action, which will not be possible without the active support of state institutions, including the creation of long-term and comprehensive strategy towards China. Among the required activities promotion of Polish products and enterprises should be emphasized and implementation of the instruments to stimulate activities of Polish companies. In addition, enhanced cooperation between China and the countries from Central and Eastern Europe represents an unquestionable opportunity to balance trade with China, as China's exports is in fact dominant in all countries of the region.

Evidence of the existing political and economic dialogue confirms the willingness and the declaration to strengthen mutual cooperation between China and the Central and Eastern European countries, including Poland. One of the significant achievements of the recent years in the relations between the CEEC and China is undoubtedly increase in mutual trust and understanding resulting largely from the dynamics of foreign trade, investment and people-to-people dialogue. The rising interdependence of the markets and a clear position of China in the XXI century as a major pro-

More discussion on the challanges and misunderstandings in cooperation with China within 16+1 see Cvetković (2016). 
ponent of globalization and international connectivity without boundaries, as put by Romanowski (2017) underline the importance of ensuring and deepening the existing openness and steps towards further liberalization. This is vital for both the CEEC and China, acting as a catalyst for economic dynamism in Europe and stimulating qualitative development of the Chinese economy.

Chinese investment provides a source of capital to stimulate growth in the markets and should therefore be accepted in Europe. Collaboration creates investment opportunities in addition to access to the Chinese market with great potential and growth prospects. Thus, foreign investments should be perceived as a crucial channel for intensification of bilateral trade. At the same time cooperation with Europe allows Chinese entrepreneurs access to the market, new technologies and skilled labor force - and in the CEEC countries relatively cheaper than in the Western Europe. As a consequence, it might create great learning opportunities - adopting good practices, acquiring leadership skills and organizational knowledge of modern management systems and technologies that can be adjusted to the national market, contributing to its further development.

Co-operation with European partners also allows Chinese investors to get to know the European market - its character, business culture, behaviour and organizational structure - necessary for success in foreign markets. The importance of European companies which are important suppliers of new technologies, business practices and good managerial skills is significant. Cooperation of European and Chinese investors in new technologies and research and development should therefore be supported, in particular in relation to the private sector, which turns out to be more effective in the implementation of new technologies, serving as engine of innovative changes. It is further crucial to attract investments with more opportunities in research and development sectors.

On the other hand, there is no doubt on the current importance of foreign direct investment in the transformation of the Chinese economy through its impact on the volume of exports, employment, technology transfer, institutional reforms and integration into the global production structures and global value chains.

Regardless of the source of the data analyzed, the fact remains, however, a small share of both Chinese foreign investment in the CEEC and the European Union, and European investments in China. At the same time, there is also cases of criticism and sceptics of Chinese investors, resulting more from existing antagonisms or insufficient knowledge of their actual size and character. Therefore, reliable monitoring with the support of gov- 
ernment agencies, and consistently providing the public with accurate information is extremely important.

Among the problems remain the lack of a clear European position towards China, and hence there is no developed strategy at the level of the European Union, or CEEC in that respect. Individual CEEC countries, including Poland, take more individual actions aimed at spurring the trade and attracting foreign investors from China on a bilateral level. In addition, that trend has been strengthened by the economic crisis, the Brexit and nationalistic tendencies in numerous European countries revealing the change in attitude of individual states towards China.

The conducted research also indicates the existing relationship between present European investment in China, and the influx of Chinese investments into the European markets. This signifies the importance of the policy of stimulating foreign direct investment. Support for investors interested in expansion into foreign markets entail investment inflows into the country - in other words, promoting European investment in China stimulates attracting Chinese investors. Lack of a coherent European policy implies the primacy of the policies of the Europeans states in terms of attracting foreign investment.

Working towards a common and coherent policy towards Chinese investment at the EU level, as well as among the CEEC, in the context of foreign investment, both inward and outward is advisable. Besides, elaborating on the guidelines for agencies of the countries involved will affect the strengthening of the common market as an investment destination.

The necessity of cohesion further relates to agencies and institutions within individual states, and thus appears to be an urgent need for coordinated action. Lack of action of that character can only weaken the competitive position of the markets, and reduce the attractiveness as a potential location for foreign investments.

Not without significance for Chinese investors remain difficulties due to the complexity and the wide variety of the European countries in terms of the nature of business, including regulations or cultural barriers. Despite the initial interest in the European market, the potential barriers may discourage potential investors. If predictions about the expansion of Chinese foreign investments prove successful they need assistance and specialized consulting in the European market. It is essential so the institution's activities to promote investment at the national level and measures to stimulate trade and investment are complementary. Competent business environment institutions market will steer potential investors and potential for reducing the cost of doing business, including transaction costs, the costs of market research and acquire the necessary information. 
Furthermore, creating a level playing field for investors, both domestic and foreign, as well as private and state will be one of the most important steps to ensure an open and non-discriminatory access to markets. It is about access to finance investment projects, tenders for public procurement, consulting and legal protection for foreign markets and guaranteeing private property. Conducting negotiations on a bilateral investment treaties and the homogeneity of the existing network of bilateral treaties on investment protection of individual European states is another key issue, which should improve the investment climate and lead to better protection of assets, particularly in the high technology and the protection of intellectual property rights. Strengthening legal protection for Chinese investors abroad, whether through bilateral or multilateral agreements, also requires reciprocity for foreign investors from Chinese site. Finally, the commitments are necessary in the context of social responsibility, thus ensuring the expected standards of safety, time and working conditions and environmental protection. The declarations should be fulfilled by all parties involved.

The observed intensification of outflow of Chinese capital in the form of foreign investment is rather the beginning of a long-term expansion, especially in the context of the New Silk Road. It is therefore important to identify areas of possible interest, including:

- sector / industry,

- a specific company,

- promotional tools,

- measures to achieve the objective,

- identify and indicate strategic partners on both sides.

Such a sequence of actions seems to be an important in the European measuring system, including relation to Chinese investment in Poland and Polish in China. However, the government's role in business relationships in China is crucial, including government agencies involved in investment promotion. It is also worth a closer look at the activities of sovereign wealth funds, such as for example China Investment Corporation (CIC), and use this knowledge to build relationships.

There is also a change of direction of the industries of Chinese foreign investments in the Europe to be observed towards high technology, infrastructure and heavy industry investment in the service sector: health care, financial services, media and entertainment, and investments in infrastructure, including telecommunications sector. Besides, there is clear dependence of the influx of Chinese foreign investment depending on the size of the market, its openness, and finally the opportunities for mergers and ac- 
quisitions, desirable acquisitions, in the form of technology, brands and distribution networks.

Important in attracting Chinese FDI will be structured approach, including the use of a large internal market. Poland has the opportunity here to attract investors whose target market would be the countries of Central and Eastern Europe. Despite a decline in the inflow of foreign direct investment, which is the result of the economic crisis, Poland remains the leader in this regard in the region of Central and Eastern Europe. Not without significance is the Polish economic situation, in particular the economic performance during the economic crisis and increase the positive reception of the investment attractiveness of our country, also for China.

Chinese investments in Europe, creates unique opportunities for access to the Chinese market. This is particularly important in the case of a minority investment, which could be a big opportunity for the expansion of the Chinese market. Given the legitimacy of the influx of Chinese direct investment into the Europeans markets, there should be also a few remarks about the investment climate. Action should be taken towards improving the investment climate in areas related to foreign investors, such as taxes. Besides, important will be activities such as facilitating visa issues or work permits. It seems necessary to also revise the activities of the existing special economic zones - both economic zones, and existing economic ties should be considered as tools to assist in attracting investors.

Marginal contacts with the region with significant economic potential were undoubtedly negligence of Polish foreign policy. So far, cooperation does not reflect the potential of China and the capabilities of our economy. Changing this situation is a challenge for Polish policy makers, and it will be possible at the expense of large expenditures to promote trade and investment.

For Poland - the biggest market among the CEEC - it seems important to identify industries in particular market niches promising use of comparative advantage and, consequently, increase economic cooperation.

Among the potential areas of cooperation are environmental protection and implementing the concept of sustainable development, renewable energy and climate change - aspects that are increasingly crucial for China. This will increase the demand for goods and services in this area. It seems that it can also be used in the processing of opportunity, especially in the agro-food sector, taking into account the growing potential of the population of the region. There are also possibilities for cooperation in the development of the service sector, including social welfare, transport and tourism and the furniture industry. Stimulation and comprehensive approach 
requires economic cooperation in all dimensions of trade, through the development of co-investment capital and research.

In detail, the following sectors seem most promising in cooperation with China:

- the market for consumer goods aimed at the middle class, in particular the industry (automotive industry, household appliances industry, processability-food),

- the luxury goods market (aerospace and yacht),

- the field of scientific and technical cooperation and research and development,

- environment protection,

- metallurgy,

- machinery industry,

- power production and machinery (cooperation in production of renewable energy and relevant machinery, including photovoltaic panels; both countries develop in this sector),

- vehicles industry - export of passengers cars spare parts and accessories to China,

- chemical industry,

- agricultural products and agriculture (export of foodstuffs, alcohol, soft drinks, agricultural machinery),

- construction industry,

- coal mining (mining machinery, methane presence measuring devices, other devices improving safety of work in coal mines),

- manufacturing of specialized aircraft in China and exports of such aircraft to China,

- machinery for paper manufacturing industry.

It should also be taken measures to develop the institutional framework of cooperation with China, both among the CEEC and within the EU and in the context of the entire Asia-Pacific region, in the dimension of bilateral relations and multilateral taking into account the Dialogue ASEAN+3, ASEM and cooperation with regional institutions, such as Asian Development Bank and AIIB. Finally, it will be necessary to harmonize institutional ties and objectives of Polish foreign policy towards China, so that they are not inconsistent with the objectives of the EU, and to further deepen the cohesion policy. It is particularly important in in the context of the New Silk Road initiative. 


\section{CONCLUDING REMARKS}

Poland and China are gradually moving towards closer and more comprehensive partnership. The bilateral relations have developed fast, particularly over the last decade which was result of, mainly, the implementation of market-oriented policies by China, further promoted by 1999 'Go Global' strategy and the country's accession to the World Trade Organisation (WTO) in 2001, and secondly - due to strengthening ties with Polish governments after implementation of the strategic partnership between China and Poland signed by the President Bronislaw Komorowski in December 2011 and comprehensive strategic partnership signed by the President Andrzej Duda in June 2016 with the presence of Chinese President Xi Jinping in Warsaw. The cooperation between Poland and China has evolved not only in economic dimension but also at the political, cultural and most of all people-to-people level, bringing some real achievements for economies and bilateral relations. China thus became very important partner of Poland. The new dimensions for strengthening ties and deepening cooperation emerged with the implementation of "16+1 Dialogue", as well as a result from the ongoing changes in the world economy and should be further explored.

The evidence of the existing progress between Poland and China over the last years, indicates that it is imperative to deepen the existing cooperation, elaborate on more comprehensive partnership and further enhance it. However, the dynamics and the expansion of China, sometimes might be and is perceived as a threat but should be rather seen as an opportunity and not only for Poland but also for other countries from the region, including Central and Eastern Europe. Overcoming existing challenges on both ends cannot be achieved by looking inward but through further global integration. Thus, closer cooperation, securing and deepening existing openness and embarking on further liberalisation of markets for the mutual benefits are recommended for all parties involved - Poland, the CEEC and China. Moreover, the growing interdependence of markets require a common and comprehensive response and the responsibility for the global issues, including climate change, security, resolving the existing conflicts and preventing the potential ones.

\section{Acknowledgements}

The article is the result of the research project "East Asia in regional cooperation and governance" financed by the National Science Centre, Poland (decision no. DEC-2013/09/B/HS4/01147). 


\section{REFERENCES}

1. Changsheng, Ch. and H. Jianwu (2014). A 10-year outlook. Falling growth potential and a new start of economic success. In Liu Shijin et. al. China's Next Decade: Rebuilding economic momentum \& balance. Hong Kong: CLSA Books.

2. Demographia (2016). Demographia World Urban Areas, 12th Annual Edition, April.

3. Eurostat (2011), Eurostat Database.

4. Eurostat (2012), Eurostat Database.

5. Eurostat (2016), Eurostat Database.

6. GUS (2016). Polish Central Statistical Office Databases.

7. Keqiang, L. (2012). "The Greatest Potential in Expanding Domestic Demand is Urbanization". People's Daily, 16th of February.

8. Nawrot K.A. (2012a), Kierunki inwestycyjne Chin. Jakich inwestycji chińskich może oczekiwać Polska - ekspertyza dla Polskiej Agencji Informacji i Inwestycji Zagranicznych i Ministerstwa Gospodarki, Warszawa, ss. 29; http://www. gochina.gov.pl/ekspertyzy_gochina.

9. Nawrot, K.A. (2012b). 中国正处在十字路口中国, 2012 年09-10月刊总第28期, 环球亚洲杂志, 14-19.

10. NBP (2017), National Bank of Poland Databases.

11. Nawrot K.A. (2013), EU-China economic relations at the beginning of the $5^{\text {th }}$ generation of the Chinese leaders, International Journal of Academic Research, Vol. 5, No 3, May, s. 373-378.

12. Nawrot K.A. (2015a), Central, Eastern Europe's road to benefits. Poland is evaluating the wind of change, China Daily, Wednesday, 25th of November 2015.

13. Nawrot K.A. (2015b). Analiza porównawcza azjatyckich megamiast na przykładzie Tokio i Delhi. In J. Kleer, Z. Strzelecki (Ed.). Megamiasta przyszło ci. Szansa czy zagrożenie rozwoju. Warszawa: Komitet Prognoz „Polska 2000 Plus” przy Prezydium PAN, 299-311.

14. Nawrot K.A. (2017), New era diplomacy to strenthen ties with CEE countries. Transcontinental sharing of goals, China Daily, Monday, 27th of November 2017.

15. Nawrot K.A. (2018). New directions in theoretical discussions, empirical research and practical cooperation for China-CEEC cooperation in the global framework, Central Compilation and Translation Bureau, Beijing (forthcoming). 
16. Oehler-Sincai, M. (2017). Budapest, Again the "Capital" of 16+1. http://www. themarketforideas.com/budapest-again-the-capital-of-161-a262/ [access: 11.12.2017].

17. PAP(2016).Powstała pierwszanaukowa siećbadawczakrajówEuropyŚr.-Wsch.i Chin.http://naukawpolsce.pap.pl/aktualnosci/news\%2C411711\%2Cpowstalapierwsza-naukowa-siec-badawcza-krajow-europy-sr-wsch-i-chin.html [access: 11.12.2017].

18. Polish Central Statistical Office Databases.

19. Romanowski, M. (2017), Where the Silk and Amber Roads Meet, Global Asia, Vol. 12, no 4, 84-89.

20. Science in Poland (2016). Establishment of the first scientific research network of Eastern and Central European countries and China. Science in Poland. Ministry of Science and Higher Education, Republic of Poland. http://scienceinpoland.pap.pl/en/news/news\%2C411766\%2Cestablishment-of-the-firstscientific-research-network-of-eastern-and-central-european-countries.html [access: 11.12.2017].

21. Cvetković V. N. (2016), The One Belt, One Road. The Balkan Perspective. Political and Security Aspects, (Ed.) V. N. Cvetković, University of Belgrade, Faculty of Security Studies, Belgrade 2016.

22. UEP (2016). Collaboration between European and Chinese scientific institutions. Poznan University of Economics and Business. http://ue.poznan. $\mathrm{pl} /$ en/news, c16/news, c15/collaboration-between-european-and-chinesescientific, a54088.html [access: 11.12.2017].

23. UNDESA (2014). United Nations, Department of Economic and Social Affairs, Population Division. World Urbanization Prospects: The 2014 Revision, CD-ROM Edition. New York.

24. Wenmeng, F. (2018). Rural-Urban Migration, Urbanization, and Megacities in China. In J. Kleer and K.A. Nawrot (Eds). The Rise of Megacities. Challanges, Opportunities and Unique Characteristics. London: World Scientific.

25. World Bank and DRC (2014). World Bank and the Development Research Center of the State Council, P. R. China. 2014. Urban China: Towards Efficient, Inclusive and Sustainable Urbanization. Washington DC: World Bank. 